\title{
Conventional and molecular diagnosis of Campylobacteriosis associated with bovine abortion
}

\author{
N. Aiswarya ${ }^{1}$, Binu K. Mani ${ }^{2}$, M. Mini ${ }^{3}$, Surya Sankar ${ }^{4}$ and M. P. Unnikrishnan ${ }^{5}$ \\ Department of Veterinary Microbiology, \\ College of Veterinary \& Animal Sciences, Mannuthy, Thrissur, Kerala - 680651 \\ Kerala Veterinary and Animal Sciences University, India.
}

Citation: Aiswarya, N., Mani, B. K., Mini, M., Sankar, S. and Unnikrishnan, M. P. 2021. Conventional and molecular diagnosis of Campylobacteriosis associated with bovine abortion. J. Vet. Anim. Sci. 52(2): 117-124. DOI: https://doi.org/10.51966/jvas.2021.52.2.117-124

Received: 07.12.2020

Accepted: 03.01.2021

Published: 01.06 .2021

\section{Abstract}

Campylobacteriosis is responsible for genital tract infections of beef and dairy herds, causing a significant economic loss in livestock sector. Campylobacter foetus species is one of the important pathogens because of its potential impact in Veterinary and Human health. This study was designed to determine the regional incidence of $C$. foetus infection in Kerala, India by isolation, detection of $C$. foetus in clinical samples by Polymerase Chain Reaction (PCR), real time PCR (qPCR), and Enzyme Linked Immunosorbent Assay (ELISA) for the detection of C. foetus antibodies in sera of bovines with the history of abortion/infertility. Clinical samples (aborted materials (50), serum (50), Cervico-Vaginal Mucus (CVM) (30) and semen samples (30)) from a total of 160 cattle and buffaloes with the history of abortion and infertility were collected. Aborted materials including placenta, foetal membranes, liver, lungs and stomach contents of the aborted foetus, semen and CVM samples were processed and subjected to isolation and identification of Campylobacter foetus subsp. foetus (Cff) and Campylobacter foetus subsp. venerealis (Cfv) and molecular confirmation by PCR and qPCR respectively. Serum samples from aborted dams were tested using indirect ELISA. All the suspected clinical samples were found negative for Cff and CfV on both culturing and PCR. All the serum samples tested were negative by ELISA as well. Conclusively the study indicated the infection of $C$. foetus spp. responsible for abortion in bovine are rare in the location where the study was conducted, which might be due to insignificant endemic levels. As per the breeding policy, only artificial insemination is practiced in Kerala in bovines, which is often considered as a simple control method for Bovine Genital Campylobacteriosis (BGC) and might be one of the factors that prevented extensive spread of $C$. foetus spp. infection.

Keywords: Campylobacteriosis, Campylobacter foetus, Bovine abortion, Polymerase Chain Reaction, real time PCR, and Enzyme Linked Immunosorbent Assay.

Part of M.V.Sc. thesis of the first author submitted to Kerala Veterinary and Animal Sciences University, Pookode, Wayanad, Kerala

1. M.V.Sc. scholar-email id: aishwarya66011508@gmail.com

2. Assistant Professor and corresponding author Email: binu@kvasu.ac.in

3. Professor and Head

4. Assistant Professor

5. Assistant Professor, Department of Animal Reproduction Gynaecology and Obstetrics

Copyright: ( $2021 \mathrm{~N}$. Aiswarya et al. This is an open access article distributed under the terms of the Creative Commons Attribution 4.0 International License (http://creativecommons.org/licenses/by/4.0/), which permits unrestricted use, distribution, and reproduction in any medium, provided the original author and source are credited. 
Reproductive performance is one of the most important factors influencing profitability in the dairy and beef industries. Though the dairy industry is very important in its contribution to the economics of both developed and the developing countries of the world, it is vulnerable to various factors which adversely affect the cattle production viz., physical, chemical, biological and environmental factors. Infectious biological agents are notable causes of reproductive failures and are being given high priority in the bovine industry (BonDurant, 2007). Infections with these agents are mainly manifested as abortion which is one of the important factors reducing calving rate and consequently causing a significant economic loss to the dairy industry (Mittal et al., 2018).

Campylobacteriosis is a widespread bacterial disease responsible for contagious genital infections and abortion in cattle around the world (Osunla and Okoh, 2017). Bovine Genital Campylobacteriosis caused by Cfv, causes significant economic impact in farming industries and requires a careful and thorough diagnosis and treatment for its control. BGC is a notifiable trade disease with countries requiring certification of disease free status of both cattle and semen for import. Campylobacter foetus subsp. foetus is associated with sporadic cases of abortion in bovines (OIE, 2018).

Bacteriological analyses of these pathogens primarily rely on cultural isolation and phenotypic characterization, which is reported to be the gold standard and confirmatory test for diagnosis of $C$. foetus infection (Brooks et al., 2004). However, isolation of $C$. foetus is labor intensive, accompanied with a high risk for potential and rapid overgrowth of more robust contaminants (Clark and Dufty, 1978). On the other hand, serological tests like ELISA was recognized as an effective screening test for detection of C. foetus (Devenish et al., 2005). However, cross- reactive antigens especially within the species pose problems for serological diagnosis (Repiso et al., 2002; More et al., 2017). Hence, to overcome these problems, nucleic acid amplification has been tremendously exploited for the routine and rapid confirmation of these pathogens (Islam et al., 2020). Various methods like PCR and
qPCR have been used for the diagnosis of Campylobacteriosis in human and domestic animals, as the tests are reliable and accurate for the species and subspecies identification of $C$. foetus (Hum et al., 1997; Chaban et al., 2012). A subspecies-specific PCR and qPCR assay for CfV targeting ISCfe-1 gene, a highly conserved, new insertion element which is present exclusively in Cfv strains (Abril et al., 2007), and for Cff targeting SapB2 gene developed by Wang et al. (2002) were employed in the present study.

The current communication reports the results of the serological and molecular diagnosis of Campylobacteriosis associated with bovine abortion in organised and unorganised livestock sectors in and around Thrissur district, Kerala.

\section{Materials and methods}

Sampling: Aborted materials, serum, CVM and semen were collected from a total of 160 cattle and buffaloes maintained in organized and unorganized farms of Kerala in India. Serum was also recovered for blood samples in separate tubes for ELISA.

Isolation: Stomach contents and pooled sample consisting of liver, lung, kidney, spleen and placenta, CVM and semen were collected aseptically in Cary-Blair medium and inoculated on the same day on Brucella agar base supplemented with five to ten per cent sheep blood and incubated at $37^{\circ} \mathrm{C}$ for $72 \mathrm{hr}$ under micro-aerophilic conditions. Similarly, reference samples received in the form of swab were subjected for inoculation.

Glycine Tolerance Test: The test was performed as described by OIE (2018). Briefly, a cell-suspension of McFarland no.1 was inoculated onto a Brucella base agar with or without $1 \%$ glycine medium and was incubated microaerobically at $37^{\circ} \mathrm{C}$ for $48 \mathrm{~h}$. The growth in the presence of glycine has been considered to be a presumptive test for $C f f$.

Reference strains: Two reference isolates (received as swab) were used in this study. Campylobacter foetus subsp. foetus 
and Campylobacter foetus subsp. venerealis were kindly provided by Institute for Veterinary Bacteriology, University of Bern, Switzerland.

\section{Genomic DNA extraction:} HiPurA ${ }^{T M}$ Multi-Sample DNA Purification Kit, Hi Media, was used for the extraction DNA from clinical samples. DNA concentration of stock solutions was measured using Nano drop (Thermo Scientific). The purity of the extracted DNA was checked by measuring the ratio of absorbance (OD of DNA preparation at 260 and $280 \mathrm{~nm}$ ). Finally, the extracted DNA was stored at $-20^{\circ} \mathrm{C}$ until use.

Campylobacter foetus subsp. foetus identification by PCR and qPCR: In the present study, genus and subspecies specific PCR and qPCR were standardized using the reference sample DNA extracted from Cff (ATCC 27374) and Cfv (NCTC 10354).

PCR was carried out using the already published Campylobacter genus specific 165 rRNA gene primers by Linton et al. (1996). The sequences of primers were: forward primer 5'- GGATGACACTTTTCGGAGC -3' and reverse primer 5'- CATTGTAGCACGTGTGTC -3'. Campylobacter foetus subsp. foetus identification was performed using specific primers published by Wang et al. (2002). The forward primer was 5'GCAAATATAAATGTAAGCGGAGAG-3' and reverse primer was 5'TGCAGCGGCCCCACCTAT-3'.

Primers for real-time PCR were designed based on sapB2 gene sequence for Cff (GeneBank Accession no. CP008808.1) using NCBI primer designing software. The forward primer was 5' TTTAGGAGCCGTATCAGCAA -3' and reverse primer was 5'- TCACCAGCAAGAGCTCCTAT -3'.

Campylobacter foetus subsp.
venerealis identification by PCR and
qPCR: The PCR and qPCR was conducted
using the primers specific for Cfv ISCfe-1 gene
(Abril et al, 2007). The forward primer was
5'- AGGCGAAGAGAATGTTAATTTGAA-3'
and reverse primer was 5'-
CCATAAAGCCTAGCTGAAAAAACTG-3'.

PCR was performed in a reaction volume of $12.5 \mu \mathrm{L}$ containing approximately $100 \mathrm{ng} / \mu \mathrm{L}$ of genomic DNA, $10 \mathrm{pM} / \mu \mathrm{L}$ of forward and reverse primer and $6.25 \mu \mathrm{L}$ of PCR master mix ((2X, Thermo Scientific).

Identification of the PCR product was doneina submarine agarosegelelectrophoresis system using one per cent agarose containing ethidium bromide, using Tris Borate EDTA buffer at a voltage of $50 \mathrm{~V}$. The gel was visualized under a UV trans-illuminator and results were documented using a gel documentation system (Biorad).

\section{SYBR green PCR protocol:}

Reactions were carried out in Eco ${ }^{\mathrm{TM}}$ Real-Time PCR System (Illumina) using 48well plates, sealed by an adhesive seals after pipetting all reagents into the wells. Reaction mixture and thermal cycling parameters are given in (Tables 2 to 4). SYBR green real-time PCR amplification plots and melt curves were viewed and analysed.

\section{C. foetus antibody ELISA} Conventional method of ELISA was performed as per the method described by Seyyal et al. (2000) with slight modifications. The immunogenicity of whole cell antigen of $C$ foetus was confirmed by AGPT and the protein concentration was standardized by Lowry's method. Hyper immune serum raised against $C$. foetus in New Zealand White male rabbits. Pre inoculation bleeding for preparation of control non-immune sera was done. A typical injection schedule consisted of $0.5 \mathrm{~mL}$ antigen $\left(2 \times 10^{8}\right.$ cells per $\mathrm{mL}$ ) on the $1^{\text {st }}$ day of inoculation. One millilitre antigen $\left(2 \times 10^{8}\right.$ cells per $\left.\mathrm{mL}\right)$ was inoculated on the $4^{\text {th }}$ day, and $2 \mathrm{~mL}$ antigen on the $7^{\text {th }}, 10^{\text {th }}, 14^{\text {th }}$ and $16^{\text {th }}$ days (Seyyal et al., 2000). The rabbits were bled by cardiac puncture one week after the last injection. The sera were separated from blood collected from two New Zealand white male rabbits and stored at $-20^{\circ} \mathrm{C}$

Checker board analysis was performed for standardizing the concentration of antigen, sera and commercial rabbit antibovine IgG peroxidase conjugate. The DAB 
Table 1: Amplification cycle for Campylobacter foetus subsp. foetus and Campylobacter foetus subsp. venerealis.

\begin{tabular}{|c|c|c|}
\hline Initial denaturation & $94^{\circ} \mathrm{C}{ }^{\circ} \mathrm{C}$ for 2 min. & \multirow{2}{*}{3 cycle } \\
\hline Denaturation & $94^{\circ} \mathrm{C}{ }^{\circ} \mathrm{C}$ for 30 sec. & \multirow{2}{*}{ cycles } \\
\hline Annealing & $61.4^{\circ} \mathrm{C}{ }^{\circ} \mathrm{C}$ for 30 sec. & \\
\hline Extension & $72^{\circ} \mathrm{C}{ }^{\circ} \mathrm{C}$ for $30 \mathrm{sec}$. & 1 cycle \\
\hline Final extension & $72^{\circ} \mathrm{C}{ }^{\circ} \mathrm{C}$ for 4 min. & \\
\hline
\end{tabular}

Table 2. Real-time PCR Reaction mix for the detection of Campylobacter foetus subsp. foetus and Campylobacter foetus subsp. venerealis

\begin{tabular}{|c|c|}
\hline Components & Volume \\
\hline Orion 2X Real time PCR smart mix & $6.25 \mu \mathrm{L}$ \\
\hline Forward primer $(10 \mathrm{pM} / \mu \mathrm{l})$ & $0.5 \mu \mathrm{L}$ \\
\hline Reverse primer $(10 \mathrm{pM} / \mu \mathrm{l})$ & $0.5 \mu \mathrm{L}$ \\
\hline Template DNA & $4.0 \mu \mathrm{L}$ \\
\hline Nuclease free water & $1.25 \mu \mathrm{L}$ \\
\hline Total & $\mathbf{1 2 . 5} \mu \mathrm{L}$ \\
\hline
\end{tabular}

Table 3. Amplification cycle for Campylobacter foetus subsp. venerealis used for real-time PCR

\begin{tabular}{|l|c|c|c|}
\hline \multicolumn{1}{|c|}{ Steps } & Temperature & Time & Number of cycles \\
\hline Initial denaturation & $95^{\circ} \mathrm{C}^{\circ} \mathrm{C}$ & $10 \mathrm{~min}$ & 1 \\
\hline Denaturation & $95^{\circ} \mathrm{C}^{\circ} \mathrm{C}$ & $30 \mathrm{sec}$ & 40 \\
\hline Annealing/Extension & $61.4^{\circ} \mathrm{C}{ }^{\circ} \mathrm{C}$ & $30 \mathrm{sec}$ & 40 \\
\hline
\end{tabular}

Table 4. Amplification cycle for Campylobacter foetus subsp. foetus used for real-time PCR

\begin{tabular}{|l|c|c|c|}
\hline \multicolumn{1}{|c|}{ Steps } & Temperature & Time & Number of cycles \\
\hline Initial denaturation & $95^{\circ} \mathrm{C}^{\circ} \mathrm{C}$ & $10 \mathrm{~min}$ & 1 \\
\hline Denaturation & $95^{\circ} \mathrm{C}^{\circ} \mathrm{C}$ & $30 \mathrm{sec}$ & 40 \\
\hline Annealing/Extension & $60.4^{\circ} \mathrm{C}{ }^{\circ} \mathrm{C}$ & $30 \mathrm{sec}$ & 40 \\
\hline
\end{tabular}

(50X) was diluted in distilled water in the ratio of $1: 20$ and used.

The extracted whole cell antigen was diluted in the coating buffer $(0.05 \mathrm{M}$ carbonate - bicarbonate buffer, $\mathrm{pH}$ 9.6), and $100 \mu \mathrm{L}$ was added to each well. The plates were incubated at $4^{\circ} \mathrm{C}$ overnight, washed three times with ELISA washing solution (Phosphate buffered saline, pH. 7.4, containing 0.5 per cent Tween20) and dried by shaking (Shaker Incubator at $180 \mathrm{rpm}, 55^{\circ} \mathrm{C}$ for $\left.20 \mathrm{~min}\right)$. One per cent bovine serum albumin in PBS-T was used to block the wells which were then subjected to incubation for one hour at $37^{\circ} \mathrm{C}$ and again washed three times with PBS-T. One hundred microlitres each of 50 serum samples of bovine having history of recent abortion (each diluted in the ratio of $1: 100)$ were loaded into the wells in duplicates and incubated for one hour at $37^{\circ} \mathrm{C}$ and washed as before. One hundred microlitres of 1:10,000 commercial rabbit anti-bovine IgG peroxidase conjugate diluted $(1: 10,000)$ was added in each well. After incubation for one hour at $37^{\circ} \mathrm{C}$, the plates were washed with ELISA washing solution and followed by loading of wells of each plate with $100 \mu \mathrm{L}$ of DAB (50X) diluted in distilled water in the ratio of 1:20. The plates 
were incubated at room temperature for $10 \mathrm{~min}$, after which the reaction was stopped using 50 $\mu \mathrm{L}$ of $1.25 \mathrm{M} \mathrm{H}_{2} \mathrm{SO}_{4}$. The optical density (OD) was measured on an ELISA reader (Biorad) at $450 \mathrm{~nm}$.

\section{Results and discussion}

Even though the isolation of causative agent is considered as the gold standard test for the diagnosis, the difficulties associated with the isolation of $C$. foetus on non-selective media have limited its practical use in the timely diagnosis (Sanhueza etal., 2014). The attempts made for isolation of $C$. foetus spp. in Brucella agar was unsuccessful for all the samples tested under the present study and Proteus was the major contaminant grown in the culture during the study. Meanwhile it was reported that reduced viability and fragile nature of the agent in clinical samples could also be affecting the culture results (Clark and Dufty, 1978; Brooks et al., 2004). Furthermore, chances of contamination with ubiquitous, faster growing microorganisms, such as Pseudomonas spp. and Proteus spp. often contaminate the samples and make it difficult to detect the presence of C. foetus (Monke et al., 2002). Many of the contaminating materials like faeces, urine or other contaminants may potentially interfere with the direct culturing (Radstrom et al., 2004). Thus the viability of $C$. foetus outside the host is important which might also get affected by the exposure to atmospheric levels of oxygen that have a toxic effect on the bacteria. These might be the reasons for unsuccessful isolation in the present study. The suppression of growth of fastidious Campylobacter by the contaminants like Proteus could also be one of the reasons for failure of isolation.

PCR offers a reliable and accurate technique for the species and subspecies identification of $C$. foetus (Hum et al., 1997) and many researchers have used this technique successfully in detecting $C$. foetus spp. DNA from clinical samples (Wang et al., 2002; Van Bergen et al., 2005). The present study also attempted to standardize genus, subspecies specific PCR and subspecies specific real time PCR for directly detecting antigens from clinical samples. The PCR primers based on SapB2 gene and ISCfe-1 gene were standardized at an annealing temperature of $61.4^{\circ} \mathrm{C}$ for 30 seconds One hundred and ten clinical specimens were subjected to PCR and all of them were found to be negative for the presence of genus specific as well as subspecies specific Campylobacter DNA. Positive controls showed respective amplicon size of $816 \mathrm{bp}, 435 \mathrm{bp}$ and $84 \mathrm{bp}$ in submarine agarose gel electrophoresis (Fig. 1-3).

Also, SapB2 gene and ISCfe-1 gene based real time PCR was standardized at an annealing temperature of $60.4^{\circ} \mathrm{C}$ and $61.4^{\circ} \mathrm{C}$ for 30 seconds using conventional PCR. Of the 160 samples, all the samples processed and tested were found to be negative. Positive controls showed an average $\mathrm{Tm}$ value of $86.4^{\circ} \mathrm{C}$ for SapB2 and $83.4^{\circ} \mathrm{C}$ for ISCfe- 1 respectively (Fig. 4-7). Then, the amplicons were visualized in three per cent agarose gel which showed band approximately at $87 \mathrm{bp}$ and $84 \mathrm{bp}$ level respectively (Fig. 8).

According to Hosseinzadeh et al. (2013), any sample could contain a mixture of semen, faeces, urine, blood or other contaminants. Many of these contaminating materials may potentially interfere with DNA extraction techniques and are also inhibitory to PCR. This might be probable reasons for unsuccessful PCR results in the present study.

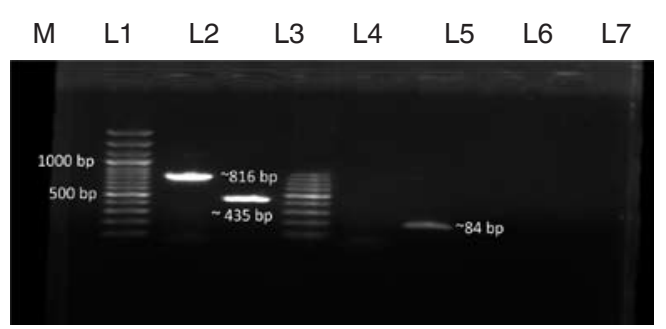

Fig.1 Agarose gel showing amplified product of Campylobacter genus and $C$. foetus subspecies specific PCR

$\mathrm{M}-100$ bp DNA ladder

L1 - Campylobacter genus (Positive control 816bp)

L2 $-C$. foetus subsp. foetus (Positive control 435bp)

L3 - 50 bp DNA ladder

L4 - Negative control

L5 - C. foetus subsp. venerealis (Positive control - 84bp)

L6 -L7 - Clinical samples 


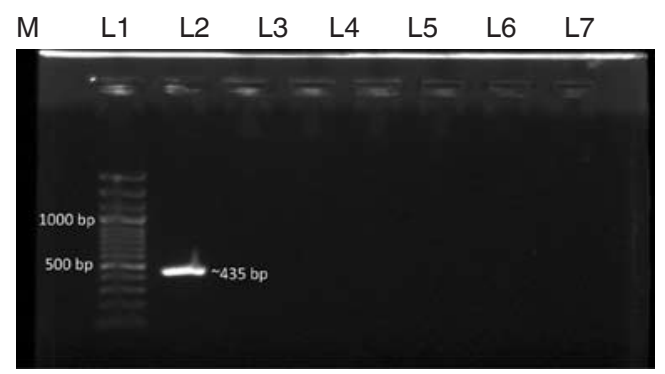

Fig.2 Agarose gel electrophoresis of PCR amplified product of $C$. foetus subspecies foetus specific PCR

M - 100 bp DNA ladder

L1 - C. foetus subsp. foetus (Positive control)

L2 - Negative control

L3 to L7 - Clinical Samples

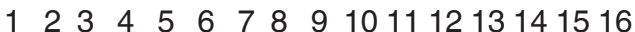

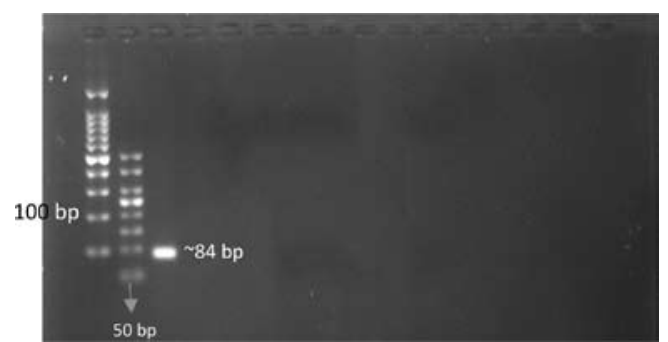

Fig.3 Agarose gel electrophoresis of PCR amplified product of $C$. foetus subsp. venerealis specific $\mathrm{PCR}$

1 - 100 bp DNA ladder

$2-50$ bp DNA ladder

3 - C. foetus subsp. venerealis (Positive control)

4 - Negative control

5 to 16 - Clinical Samples

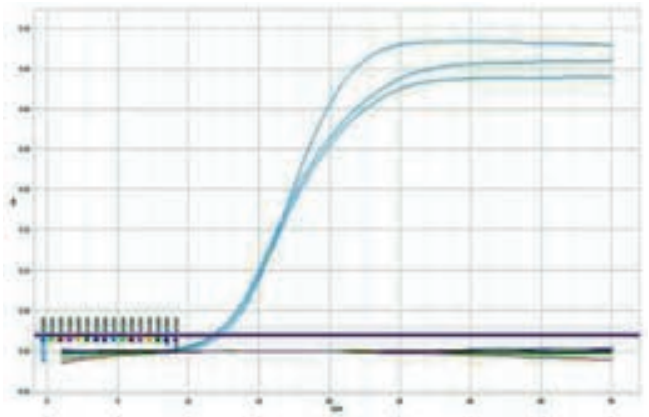

Fig. 4 Amplification plot of real time PCR assay for SapB2 gene from positive control and clinical samples

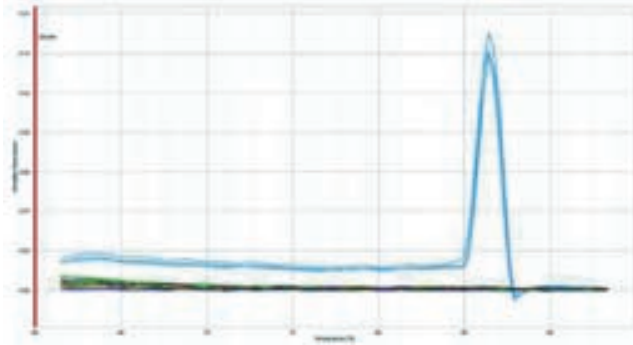

Fig. 5 Melt curve of real time PCR assay for SapB2 gene from positive control and clinical samples

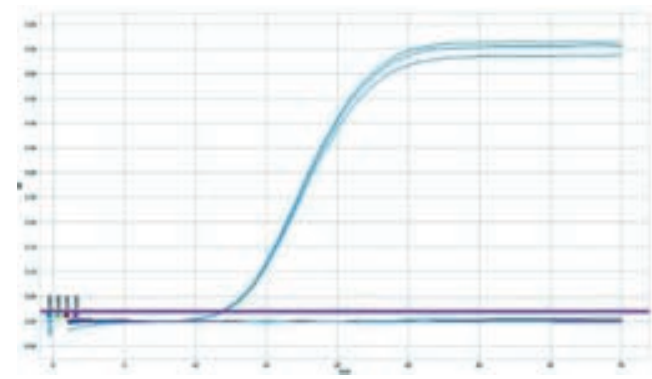

Fig. 6 Amplification plot of real time PCR assay for ISCfe-1 gene from positive control and clinical samples

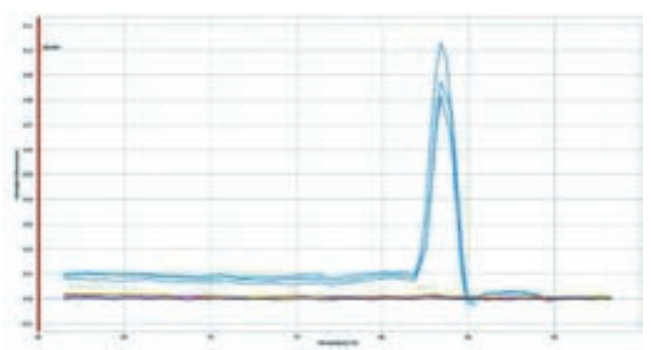

Fig. 7 Melt curve of real time PCR assay for ISCfe-1 gene from positive control and clinical samples

Furthermore, the reportof nocampylobacteriosis case from 160 clinical samples processed might be due to insignificant endemic levels in the location, where the study was conducted. This assumption is supported by the results of Mani (2014), where he could not detect any $C$. foetus organism from the samples of infertility and abortion from bovines in the same area.

Similarly, ELISA was standardized for detecting antibodies from clinical samples. Initially the optimum concentrations of the antigen, antibody and IgG-HRP conjugate was calculated employing checker board analysis. It was observed that antigen concentrations (10 
$\begin{array}{lllllllll}M & \text { L1 } & \text { L2 } & \text { L3 } & \text { L4 } & \text { L5 } & \text { L6 } & \text { L7 }\end{array}$

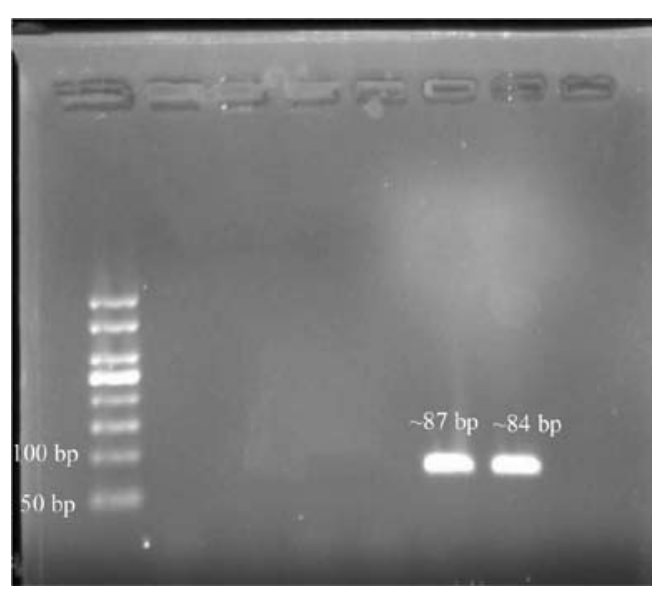

Fig. 8 Standardisation of SapB2 and ICSfe-1 gene using conventional PCR with product size $87 \mathrm{bp}$ and $84 \mathrm{bp}$

$\mathrm{M}-50$ bp DNA ladder

L1-L4 - Negative control

L5 - C. foetus subsp. foetus (Positive control87bp)

L6 - C. foetus subsp. venerealis (Positive control - 84bp)

$\mu \mathrm{g} / 100 \mu \mathrm{L}$ ) of $50 \mathrm{ng}$ per well for SapB2 were found optimum at a test sera dilution of 1:100.

In order to determine the cut off value for demarcating the negative and positive sera samples, the ELISA was conducted employing the whole cell antigen antibody and IgG-HRP conjugate and the cut off values obtained were 0.12 . A total of 50 suspected bovine serum samples were screened using the ELISA and all the serum samples were found to be negative. The high frequency of negative samples observed while performing ELISA might be due to factors such as better awareness regarding contagious disease among farmers, improved husbandry practices, climatic and geographic aspect of the area under study.

The work did not provide any proof of absence of the organism but the weight of evidence indicates that infection was highly unlikely to be widespread in herds. Artificial insemination is often considered as a simple control method for BGC, but is impractical for many herds where natural service takes place as a part of breeding. As per the breeding policy, only artificial insemination is practiced in Kerala in bovines, which might be one of the factors that prevent extensive spread of BGC.

\section{References}

Abril, C., Vilei, E.M., Brodard, I., Burnens, A., Frey, J. and Miserez, R. 2007. Discovery of Insertion Element ISCfe-1: A new tool for Campylobacter foetus subspecies differentiation. Clin. Microbiol. Infect. 13: 993-1000.

BonDurant, R.H. 2005. Venereal diseases of cattle: natural history, diagnosis, and the role of vaccines in their control. Vet. Clin. North Am. Food Anim. Pract. 21: 383408.

Brooks, B.W., Devenish, J., Wallace, C.L.L., Milnes, D., Robertson R.H. and Surujballi, G.B. 2004. Evaluation of a monoclonal antibody based ELISA for detection of $C$. foetus in bovine perputial washing and vaginal mucus samples. Vet. Microbiol. 103: 77-84.

Chaban, B., Garcia Guerra, A., Hendrick, S.H., Waldner, C.L. and Hill, J.E. 2013. Isolation rates of Campylobacter foetus subsp. venerealis from bovine preputial samples via passive filtration on nonselective medium versus selective medium, with and without transport medium. Am. J. Vet. Res. 74: 10661069.

Clark, B.L. and Dufty, J.H. 1978. Isolation of Campylobacter from bulls. Aust. Vet. J. 54: 262-263.

Devenish, J., Brooks, B., Perry, K., Milnes, D., Burke, T., McCabe, D., Duff, S. and Lutze-Wallace, C.L. 2005. Validation of a monoclonal antibody-based capture enzyme-linked immunosorbent assay for detection of Campylobacter foetus. Clin. Diagn. Lab. Immunol. 12: 1261-1268.

Hosseinzadeh, S., Kafi, M. and Pour-Teimouri, M. 2013. PCR detection of Campylobacter fetus subspecies venerealis in smegma samples collected from dairy cattle in Fars, Iran. Vet. Res. Forum. 4:227-231. 
Hum, S., Quinn, K. and Brunner, J. 1997. Evaluation of a PCR assay for identification and differentiation of Campylobacter foetus subspecies. Aust. Vet. J. 75: 827-831.

Islam, S., Shehzad, W., Bajwa, A.A., Imran, M., Zahoor, M.Y., Abdullah, M., Rashid, M.I., Ashraf, K., Chang, Y., Nadeem, A., Younas, M., Bukhari, S.A.M., Hassan, M.M., Qureshi, Z.I. and Akhtar, R. 2020. Molecular Detection of Brucellosis, Leptospirosis and Campylobacteriosis by Multiplex PCR and Screening by ELISA Assays in Buffalo Breeding Bulls. Pakist. Vet. J. 40: 81-87.

Mani, B.K. 2014. Standardization of multiplex PCR and ELISA as a diagnostic protocol for the bacterial abortions in ruminants. Ph.D thesis, Kerala Veterinary and Animal Sciences University, Pookode, $101 p$.

Mittal, M., Sharma, V. and Nehra, K. 2018. Abortions in an organized dairy farm from North India reveal the possibility of breed susceptibility to Bovine Brucellosis. One HIth. 5: 1-5.

Monke, H.J., Love, B.C., Wittum, T.E., Monke, D.R. and Byrum, B.A. 2002. Effect of transport enrichment medium, transport time, and growth medium on the detection of Campylobacter foetus subsp. venerealis. J. Vet. Diagn. Invest. 14: 35-39.

More, S., Botner, A., Butterworth, A., Calistri, P., Depner, K., Edwards, S., Bastuji, B.G., Good, M., Schmidt, C.G.A., Michel, V., Miranda, M.A., Nielsen, S.S., Raj, M., Sihvonen, L., Spoolder, H., Stegeman, J.A., Thulke, H.H., Velarde, A., Willeberg, P., Winckler, C., Baldinelli, F., Broglia, A., Candiani, D., Beck, B.B., Kohnle, L. and Bicout, D. 2017. Assessment of listing and categorisation of animal diseases within the framework of the Animal Health Law (Regulation (EU) No 2016/429): bovine genital campylobacteriosis. EFSA. J. 15: 4990.
O.I.E. [World Organisation for Animal Health]. 2018. Bovine Genital Campylobacteriosis. In: OIE Terrestrial Manual. World Organisation for Animal Health. Paris, France, pp. 1031-1044.

Osunla, C.A. and Okoh, A.I. 2017. Vibrio pathogens: A public health concern in rural water resources in Sub-Saharan Africa. Int. J. Environ. Res. Public. Hith. 14: 1188-1215.

Radstrom, P., Knutsson, R., Wolffs, P., Lovenklev, M. and Lofstrom, C. 2004. Pre-PCR processing: Strategies to generate PCR-compatible samples. Mol. Biotech. 26: 133-146.

Repiso, M.V., Baraibar, M.A., Olivera, M.A, Silveyra, S. and Battistoni, J. 2002. Development and evaluation of an enzyme-linked immunosorbent assay for quantification of the humoral response of cattle vaccinated against Campylobacter foetus. Am. J. Vet. Res. 63: 586-590.

Sanhueza, J.M., Heuer, C., Jackson, R., Hughes, P., Anderson, P., Kelly, K. and Walker G. 2014. Pregnancy rates of beef cattle are not affected by Campylobacter foetus subsp. venerealis real-time PCRpositive breeding sires in New Zealand. N.Z. Vet. J. 62: 237-243.

Seyyal, A.K., Turan, N., Kemal, A.K., Ileri, K. andllgaz, A. 2000. Use of ELISA, IFA, and avidin-biotin staining for the diagnosis of bovine genital campylobacteriosis. Turk. J. Vet. Anim. Sci. 24: 113-121.

Van Bergen, M.A.P., Linnane, S., Van Putten, J.P. and Wagenaar, J.A. 2005. Global detection and identification of Campylobacter foetus subsp. venerealis. Rev. Sci. Tech. 24: 1017-1026.

Wang, G., Clark, C.G., Taylor, T.M., Pucknell, C., Barton, C., Price, L., Woodward, D.L. and Rodgers, F.G. 2002. Colony multiplex PCR assay for identification and differentiation of Campylobacter jejuni, C. coli, C. lari, C. upsaliensis, and C. foetus subsp. fetus. J. Clin. Microbiol. 40: 4744-4747. 